\title{
Komunikasi Termediasi dan Momentum Revitalisasi Pembelajaran Daring ${ }^{1}$
}

\author{
Eka Nada Shofa Alkhajar \\ Universitas Sebelas Maret, Surakarta
}

\section{Pendahuluan}

Seantero dunia saat ini, tengah dirundung duka dan dibaluti kesedihan akibat sebuah penyakit bernama Coronavirus Disease 2019 (COVID-19). Penyakit tersebut disebabkan oleh virus baru yang disebut sebagai Severe Acute Respiratory Syndrome Coronavirus 2 (SARS-CoV-2). Penyakit ini pertama kali muncul dan merebak di Kota Wuhan, Provinsi Hubei, Tiongkok. Kota tersebut lantas menjadi episentrum awal COVID-19. Tak berselang lama, penyakit ini kemudian menyebarluas ke seluruh penjuru dunia.

Organisasi Kesehatan Dunia (World Health Organization, WHO) pun mengumumkan status COVID-19 sebagai sebuah pandemi global pada 11 Maret 2020. COVID-19 telah menjangkiti lebih dari 200 negara di dunia. Hingga saat ini setidaknya tercatat lebih dari 5 juta orang yang terinfeksi penyakit tersebut. Sementara itu, angka kematian yang diakibatkan oleh penyakit ini mencapai lebih dari 300 ribu jiwa. Angka ini bukanlah angka final. Angka tersebut diprediksi masih akan terus bertambah dari waktu ke waktu apabila upaya pencegahan dan penanganan untuk memutus mata rantai penularan tidak dapat dilakukan dengan baik.

Banyak pihak yang mengatakan angka berkenaan dengan COVID-19 bukanlah sesuatu yang patut diikuti sebagaimana lazimnya mengikuti angka dalam sebuah pertandingan olahraga. Apalagi hal tersebut dapat menimbulkan kecemasan berlebihan yang mana dapat menurunkan imunitas tubuh sehingga menjadikan diri rentan tertular COVID-19. Dalam poin untuk menghindari efek negatif menurunnya imunitas tubuh penulis setuju dengan pandang tersebut.

Namun, untuk pihak otoritas atau kalangan terkait, angka tersebut harus senantiasa dipantau, dibaca, dan dicermati secara baik karena angka tersebut merupakan salah satu informasi penting mengenai situasi dan perkembangan

\footnotetext{
${ }^{1}$ Sumber Naskah:

Alkhajar, E. N. S. (2020). Komunikasi Termediasi dan Momentum Revitalisasi Pembelajaran Daring. In E. N. S. Alkhajar \& S. H. B. Wijaya (Eds.), Dinamika Komunikasi dalam Pandemi COVID-19 (pp. 181-194). Yogyakarta: KBM Indonesia.
} 
terkini berkaitan dengan COVID-19. Saat ini, Amerika Serikat tercatat sebagai episentrum baru COVID-19 di mana terdapat lebih dari 1,5 juta orang terinfeksi penyakit tersebut. Kita semua tentu berharap agar pandemi yang tengah menyapa dan menghantui dunia ini segera berakhir. Apalagi pandemi ini terbukti sudah menghadirkan banyak persoalan di berbagai sektor dan aspek kehidupan manusia.

Ironisnya, di tengah pandemi ini, justru banyak bermunculan apa yang disebut sebagai paradoks kemanusiaan. Sebuah kondisi di mana manusia hanya memikirkan nasib dan keuntungan diri sendiri tanpa memperdulikan orang lain sehingga sampai hati melakukan hal-hal di luar nalar kemanusiaan. Penimbunan masker adalah salah satu contohnya (Wijaya \& Alkhajar, 2020). Selain itu, banyak pula bertebaran hoaks yang berkaitan dengan pandemi COVID-19 di saat publik benar-benar memerlukan informasi yang sahih dan akurat. Menurut seorang pakar, kurangnya kompetensi etis dari sebagian warganet yang tidak berbanding lurus dengan penguasaan dan keterampilan teknis penggunaan teknologi adalah salah satu alasan mengapa hoaks merajalela (Wijaya, 2019). Padahal, hoaks sangat berbahaya bagi kesehatan informasi publik. Hoaks dapat menyesatkan publik, memperkeruh situasi yang ada hingga memicu terjadinya berbagai hal destruktif lainnya (Wijaya \& Alkhajar, 2020).

Secara umum, kesadaran semua pihak merupakan modal penting yang sangat diperlukan dalam upaya melawan COVID-19. Kesadaran kolektif ini sesungguhnya merupakan garda utama untuk meminimalisasi penyebaran virus Corona sekaligus membantu para tenaga medis yang berjuang menangani para pasien yang terinfeksi di rumah sakit. Pandemi adalah ujian bagi kita bersama. Sebuah ujian sempurna bagi kualitas bangsa kita dalam menghadapi situasi pandemi. Untuk itu, kita harus dapat bergotong-royong dan bahu-membahu membantu pemerintah dalam upaya pencegahan dan penanganan COVID-19. Di sisi lain, kita pun sangat berharap agar pemerintah dapat mengoptimalkan berbagai kebijakan yang telah diambil seraya tetap melindungi dan membantu warga yang terdampak akibat adanya pandemi.

\section{Adaptasi dan Dinamika Pembelajaran Daring}

Kembali kepada berbagai persoalan akibat pandemi COVID-19, dunia pendidikan merupakan salah satunya bidang yang terdampak hebat. Tidak terkecuali dengan dunia pendidikan di Indonesia. Sesuai arahan pemerintah, dunia pendidikan kita diminta untuk melaksanakan proses pendidikan melalui ruang virtual. Dengan kata lain, proses pembelajaran mesti beralih dari pembelajaran konvensional yang biasa dilakukan di ruang kelas menjadi pembelajaran dalam jaringan (daring) atau pembelajaran jarak jauh (PJJ) yang dapat dilakukan di rumah atau lokasi manapun yang dirasa aman dari ancaman COVID-19. Tentunya, dengan memanfaatkan teknologi informasi dan komunikasi (TIK). Ini 
semua dilakukan sebagai langkah untuk memutus mata rantai penyebaran COVID-19 sekaligus melindungi keselamatan masyarakat dunia pendidikan di tanah air. Terlebih pembelajaran daring adalah satu-satunya cara yang dapat ditempuh mengingat kondisi pandemi. Oleh karena itu, pembelajaran daring tak lain merupakan solusi terbaik bagi dunia pendidikan di masa pandemi seperti saat ini.

Meskipun COVID-19 memberi dampak pada dunia pendidikan secara umum namun tulisan ini lebih memfokuskan bahasan pada lingkup pembelajaran daring di perguruan tinggi. Salah satu alasan utamanya tak lain adalah karena kedekatan dengan dunia keseharian serta latar belakang profesi penulis sendiri. Seperti diungkapkan sebelumnya, di berbagai perguruan tinggi di Indonesia, proses pembelajaran dan dialektika pengetahuan yang biasanya dilakukan secara konvensional melalui komunikasi secara langsung atau face-to-face (tatap muka) kini berubah menjadi komunikasi termediasi (mediated communication), baik itu menggunakan perangkat komputer (computer-mediated communication) ataupun perangkat mobile (mobile-mediated communication). Semua perangkat seperti komputer personal (personal computer), laptop, komputer portabel, ponsel cerdas (smartphone), hingga laptop tersebut tentunya harus terkoneksi dengan jaringan internet.

Pandemi memaksa dunia kampus beradaptasi dan bertransformasi secara cepat dalam penyelenggaraan proses pembelajaran daring. Pertemuan tatap muka secara fisik dalam proses pembelajaran kini tak lagi dijumpai. Hal tersebut memang dihindari terutama berkaitan dengan pembatasan fisik (physical distancing). Ruang pembelajaran kini tak lagi dimaknai sebagai kelas-kelas dalam artian fisik tetapi telah bertransformasi menjadi kelas-kelas virtual dengan perantaraan teknologi.

Dalam konteks Indonesia, pembelajaran daring di dunia kampus sesungguhnya bukan sebuah hal baru. Banyak kampus yang telah mengaplikasikannya dalam proses pembelajaran. Sebagian dari kampus tersebut bahkan telah memiliki kapasitas pembelajaran daring yang mumpuni. Meskipun memang, sekali lagi, kondisi tersebut bukanlah sebuah gambaran ideal dan menyeluruh yang ada di dunia kampus kita. Oleh karena itu, perubahan secara tiba-tiba dari pembelajaran konvensial ke pembelajaran daring karena adanya pandemi tetap menjadi sebuah tantangan tersendiri. Kita bisa melihat proses adaptasi dan praktik tersebut tidak dilakukan secara gradual tetapi berlangsung cepat dan mendadak.

Kondisi dan realitas baru ini pun menghadirkan dinamika tersendiri. Sebagian besar dari kita tentu pernah membaca berita, menemukan bahkan merasakan adanya dinamika pembelajaran daring di tengah pandemi. Dalam beberapa kesempatan, dinamika tersebut bahkan sempat memunculkan sedikit 
ketegangan antara mahasiswa dengan dosen ataupun mahasiswa dengan kampus. Kehadiran dinamika tentu saja baik sejauh dinamika tersebut berada dalam kerangka konstruktif dan bukan malah sebaliknya.

Lebih lanjut, di tengah pandemi yang ada, dunia kampus terus bergerak untuk tetap merawat eksistensi pendidikan agar tetap bergulir dan berjalan melalui pembelajaran daring. Dengan kata lain, dunia kampus telah berjuang keras untuk memastikan agar pendidikan sebagai instrumen penting bagi kemajuan bangsa tidak mandek (Alkhajar, 2014). Dalam proses pembelajaran daring, para pendidik menggunakan berbagai aplikasi seperti grup WhatsApp, Google Meet, Google Classroom, Edmodo, dan Zoom. Dengan berbagai tantangan yang ada, para pendidik terus berupaya untuk mendialogkan ilmu pengetahuan kepada para peserta didik.

Komunikasi pengetahuan pun berlangsung secara daring dan tidak dibatasi ruang yang mana sesungguhnya dapat membuka berbagai kesempatan dan terobosan baru dalam dunia pembelajaran. Sementara itu, bentuk komunikasi termediasi yang ada di masa pandemi sekarang ini menandai semakin menguatnya ruang siber ataupun interaksi virtual di era media kedua (second media age). Sebuah era di mana interaktivitas (interactivity) merupakan kata kunci penting yang ada didalamnya (Poster, 1995; Holmes, 2005). Berbagai interaksi virtual yang masif terjadi di masa pandemi ini pun kian memperkuat salah satu tipologi gagasan interaksi yang dimunculkan oleh John B. Thompson (1995), yakni interaksi termediasi (mediated interaction).

Di sisi lain, apa yang terjadi hari ini juga menegaskan apa yang pernah diungkapkan oleh seorang pakar dan teoritisi media bernama Neil Postman lebih dari tiga dekade silam. Postman (1985), ketika itu, menuturkan bahwa setiap zaman akan melahirkan sistem ataupun bentuk konversasinya sendiri. Kini kita dapat melihat bersama bahwa komunikasi termediasi telah menjadi sebentuk sistem konversasi di masa pandemi.

\section{Habitus dan Blessing in Disguse}

Tak ada seorang pun yang menghendaki kehadiran pandemi COVID-19. Apalagi pandemi tersebut telah merenggut ratusan ribu nyawa dan menginfeksi jutaan penduduk di muka bumi ini. Pandemi yang terjadi bahkan telah membawa umat manusia ke dalam situasi krisis yang memilukan. Meskipun demikian, pandemi nyatanya juga membawa keberkahan yang tak disangka-sangka sebelumnya. Ini sesuai dengan sebuah idiom yang berbunyi "blessing in disguse."

Perusahaan teknologi komunikasi bernama Zoom, misalnya, merupakan salah satu perusahaan yang menangguk keuntungan berlipat di tengah pandemi Corona. Nilai saham perusahaan penyedia layanan meeting dan video conferencing daring tersebut meroket seiring dengan bertambahnya para 
pengguna layanan tersebut (Reinicke, 2020). Hal ini tidaklah mengherankan karena Zoom telah menjadi andalan bagi banyak sektor di tengah pandemi seperti sosial, bisnis, pemerintahan, hingga dunia pendidikan.

Seperti telah disinggung sebelumnya, meski dalam derajat tertentu mengalami kendala dalam proses adaptasi dan transformasi ke arah pembelajaran daring namun dunia pendidikan kita terbukti dapat melakukannya dengan baik. Apresiasi tinggi tentu harus dialamatkan kepada semua pihak di seluruh perguruan tinggi di Indonesia karena mampu adaptif dengan kondisi pandemi seperti sekarang. Ini penting karena terkadang kita kerap lupa untuk mengapresiasi diri kita secara baik sehingga hanya melihat sesuatu dari kacamata kekurangan.

Namun, perlu diakui bahwa kondisi pandemi ini merupakan medan sempurna untuk melatih para pendidik dan peserta didik untuk semakin terbiasa berinteraksi dan berkomunikasi secara termediasi dalam kerangka pembelajaran daring. Pandemi juga memaksa terjadinya suatu akselerasi praktik pembelajaran daring secara masif dan menyeluruh termasuk di dalamnya adalah kemampuan dan keterampilan untuk menguasai berbagai sarana yang diperlukan. Dalam bahasa Elias dan Merriam (1980), pandemi membuat semua orang menyelaraskan antara teori dan praktik berkenaan dengan pembelajaran daring.

Kondisi demikian akhirnya membuat pembelajaran daring ini menjadi sangat familiar dan populer dalam waktu singkat. Ini terjadi karena semua orang dalam dunia pendidikan berkonsentrasi secara penuh untuk tetap bisa menyelenggarakan dan mengikuti proses pendidikan melalui pembelajaran daring. Kenyataan semacam ini dapat dimaknai sebagai sebuah berkah karena bisa jadi untuk sampai pada titik di mana kita berada sekarang akan memerlukan waktu yang lebih lama apabila tidak ada pandemi. Meminjam istilah Pierre Bourdieu (2004), perlahan tanpa disadari pandemi telah membantu dunia pendidikan kita bergerak ke arah habitus baru. Sebuah habitus yang terbangun secara cepat dan intens hingga akhirnya membentuk sebuah pola kebiasaan unik. Pola kebiasaan unik ini bahkan menjadi semacam kondisi normal baru di tengah pandemi yang sedang berlangsung.

Seperti diuraikan Bourdieu, habitus dapat terbentuk sebagai produk dari pengkondisian sosial. Salah satunya berkenaan dengan physical distancing akibat pandemi. Kita tentu harus bersyukur atas terbentuknya habitus pembelajaran daring ataupun habitus dialektika pengetahuan daring karena hasil dari habitus ini tidak hanya akan kita nikmati di saat pandemi semata tetapi akan terus dapat kita nikmati bahkan setelah pandemi berakhir.

Habitus dialektika pengetahuan daring yang kini merebak hebat mulai dari diskusi, seminar, kuliah umum, konferensi hingga berbagai ruang-ruang ilmiah lainnya bahkan membuat sirkulasi pengetahuan menjadi semakin deras. Ada sekat-sekat pengetahuan yang semakin terbuka dengan adanya habitus baru ini. 
Hal ini terjadi karena orang-orang semakin mudah untuk terkoneksi tanpa batas dan lintas sektoral. Orang-orang dapat menikmati, mengalami dan berpartisipasi bersama dalam sebuah forum dialektika melalui layar yang ada di perangkat mobile atau komputer mereka secara langsung. Kenneth J. Gergen (2002), menyebut konsep ini sebagai "absent presence." Sebuah konsep yang kemudian diterjemahkan secara apik oleh Mimi Sheller dan John Urry sebagai "being in a sense present while apparently absent" (2006: 207). Kita hadir di ruang-ruang tersebut namun kita tidak hadir secara fisik.

Seperti penulis sebutkan sebelumnya, habitus dialektika pengetahuan daring semacam ini akan masif terjadi tidak hanya di lingkup perguruan tinggi an sich tetapi lintas sektoral dan lintas institusi. Kolaborasi dalam kerangka dialektika pengetahuan akan semakin banyak terjadi di internal kampus, lintas kampus, kampus-kementerian, kampus-lembaga negara maupun kampus dengan institusi-institusi lainnya. Praktik-praktik ini dapat dipastikan akan semakin menjamur bak cendawan di musim hujan. Dunia kampus tentu saja akan memperoleh banyak keuntungan di tengah pandemi dalam konteks sirkulasi dan dialektika pengetahuan sesuai dengan idiom "blessing in disguse." Hal ini tentu saja menjadi modal penting dalam praktik transfer dan dialektika pengetahuan dalam dunia pendidikan kita ke depan.

Meskipun demikian, penulis percaya habitus sesungguhnya merupakan sebuah proses konstruksi yang tak akan pernah berakhir di mana segala kemungkinan dan potensi perubahan masih terbuka untuk mengada. Apapun itu, perubahan adalah sebuah keniscayaan. Tidak ada hal lain yang dapat dilakukan selain mempersiapkan diri sebaik-baiknya untuk menyongsong dan menikmati hadirnya perubahan. Selain itu, disadari atau tidak, pandemi yang terjadi ini telah mengubah banyak hal dalam kehidupan. Pandemi telah mengubah diri kita untuk selamanya. Setidaknya, dari sisi bagaimana kita memandang dunia. Satu hal yang pasti, lapisan-lapisan pengetahuan dan pengalaman yang tercipta dan terbentuk di masa pandemi merupakan bekal berharga bagi siapapun untuk menapaki masa depan yang lebih baik.

\section{Momentum Terbaik}

Pandemi COVID-19 adalah sebuah realitas kehidupan yang tak terbantahkan. Kelak, pandemi ini akan menjadi salah satu pandemi yang paling bersejarah karena dampak hebat yang ditimbulkannya. Betapa tidak, pandemi telah mengubah dan mempengaruhi berbagai lini kehidupan. Mulai dari hal-hal yang bersifat duniawi hingga ukhrawi. Meskipun demikian, kita semua harus mampu mengambil hikmah dan pelajaran positif. Dalam dunia pendidikan, pandemi telah mengajar kita bersama sesuatu yang sangat berharga dan tak ternilai berkenaan dengan urgensi pembelajaran daring dan teknologi digital. Kita 
berharap besar bahwa pandemi ini semakin menyadarkan banyak pihak terutama para pemegang kebijakan dan otoritas terkait di tanah air untuk terus meningkatkan sistem pembelajaran daring dari waktu ke waktu.

Pengalaman pembelajaran daring di masa pandemi menyiratkan sebuah pesan penting bahwa sistem pembelajaran daring yang mumpuni adalah sesuatu yang mutlak dan tak bisa ditawar. Termasuk tentunya dalam hal perluasan sarana, prasarana, akses dan teknologi yang memadai bagi seluruh perguruan tinggi di Indonesia. Pandemi adalah momentum terbaik dalam upaya merevitalisasi sistem pembelajaran daring di dunia pendidikan kita. Ini adalah sebuah kesempatan emas yang tidak boleh dilewatkan begitu saja dikarenakan kini orang-orang telah berada dalam satu frekuensi yang sama dan bergerak ke arah pembelajaran daring akibat adanya situasi pandemi.

Kita pun berharap sistem pembelajaran daring tidak hanya dapat menjadi sarana pembelajaran alternatif tetapi juga mampu menjadi sebuah kombinasi sistem pembelajaran yang bagus dan berkualitas. Bahkan tidak menutup kemungkinan akan menjadi salah satu arus utama proses pembelajaran di negeri ini sebagaimana telah ditunjukkan oleh praktik di banyak perguruan tinggi. Salah satu yang paling berpengalaman tentunya adalah Universitas Terbuka (UT).

Di Indonesia, konsep dan praktik blended learning memang telah dilaksanakan. Meskipun begitu, kita perlu mengakui masih terdapat celah dan kekurangan dalam ranah praktiknya. Kementerian Pendidikan dan Kebudayaan pun telah memiliki platform pembelajaran daring bernama SPADA (Sistem Pembelajaran Daring) di mana terdapat 250 perguruan tinggi telah ikut berpartisipasi di dalamnya (Direktorat Jenderal Pendidikan Tinggi, 2020). Kita harus mengakui bahwa SPADA telah berkontribusi besar dalam menunjang proses pembelajaran termasuk dalam upaya distribusi dan diseminasi pengetahuan kepada publik secara lebih luas. Hal ini jelas merupakan sebuah prestasi hebat sekaligus menjadi modal penting dari eksistensi SPADA. Namun, kita juga tidak dapat menutup mata dan telinga bahwa masih banyak keluhan yang terlontar berkenaan dengan kualitas SPADA terutama di masing-masing perguruan tinggi.

Hal tersebut merupakan kondisi riil yang ada di mana di sebagian kampus keberadaan platform tersebut belum dapat mendukung proses pembelajaran daring secara maksimal. Oleh karena itu, tak heran apabila banyak pendidik yang lebih memilih menggunakan berbagai media lain yang dirasa lebih mudah dan efektif dalam proses pembelajaran daring di tengah pandemi. Untuk itu, upaya-upaya perbaikan oleh pihak-pihak terkait harus segera dilakukan untuk meningkatkan kualitas SPADA maupun platform sejenis agar dapat menjadi sarana pembelajaran daring yang mumpuni. 


\section{Penutup}

Pandemi jelas membawa perubahan signifikan dalam proses pembelajaran yang tentu saja tidak selalu mudah melakukan penyesuaian terhadapnya. Meski demikian, kita harus selalu siap untuk melangkah ke depan karena kehidupan baru memang harus dimulai. Kita percaya bahwa dunia pendidikan akan senantiasa mampu beradaptasi secara baik. Apalagi bangsa Indonesia memang sudah lama dikenal sebagai bangsa yang tidak kenal menyerah. Sejarah bangsa di masa lalu telah membuktikan hal tersebut. Betapa Indonesia terbukti memiliki kekuatan dan kemampuan luar biasa untuk melewati berbagai tantangan dengan baik. George McTurner Kahin (1970), seorang Indonesianis bahkan sangat yakin akan kualitas bangsa Indonesia. Kahin percaya bangsa Indonesia akan selalu bisa mengatasi setiap persoalan yang datang dengan kualitas sama baiknya sebagaimana bangsa ini pernah menghadapi berbagai kondisi sulit di masa lalu. Akhir kata, maju terus dunia pendidikan Indonesia.

\section{Daftar Pustaka}

Alkhajar, E. N. S. (2014). Media, masyarakat dan realitas sosial. Surakarta: Sebelas Maret University Press.

Bourdieu, P. (2004). In other words. Cambridge: Cambridge University Press.

Direktorat Jenderal Pendidikan Tinggi. (2020). Berbagi pengetahuan, modul pembelajaran, dan perkuliahan secara daring lewat SPADA. Siaran Pers No. 035/Sipers/IV/2020. Direktorat Jenderal Pendidikan Tinggi. Kementerian Pendidikan dan Kebudayaan.

Elias, J. L., \& Merriam, S. (1980). Philosophical foundations of adult education. Malabar, FL: Robert E. Krieger.

Gergen, Kenneth J. (2002). The challenge of absent presence. In J. E. Katz \& M. Aakhus (Eds.), Perpetual contact (pp. 227-241). Cambridge: Cambridge University Press.

Holmes, D. (2005). Communication theory: Media, technology and society. Thousand Oaks, CA: Sage Publications.

Kahin, G. M. (1970). Nationalism and revolution in Indonesia. Ithaca, NY: Cornell University Press.

Poster, M. (1995). The second media age. Cambridge: Polity Press.

Postman, N. (1985). Amusing ourselves to death. New York: Viking.

Reinicke, C. (2020, March 23). Zoom Video has seen its stock spike more than $100 \%$ since January as coronavirus pushes millions to work from home (ZM). Business Insider. Retrieved April 22, 2020, from 
https://markets.businessinsider.com/news/stocks/zoom-stock-price-surgedcoronavirus-pandemic-video-work-from-home-2020-3-1029023594

Sheller, M., \& Urry, J. (2006). The new mobilities paradigm. Environment and Planning A, 38(2), 207-226.

Thompson, J. B. (1995). The media and modernity: A social theory of the media. Stanford: Stanford University Press.

Wijaya, S. H. B. (2019). Seri literasi media: Dari hoax hingga hacking. Yogyakarta: Buku Litera.

Wijaya, S. H. B., \& Alkhajar, E. N. S. (2020). Memotret pandemi: Hoaks Covid19 dan paradoks kemanusiaan. In F. Junaedi (Ed.), Krisis komunikaasi dalam pandemi Covid-19 (pp. 229-233). Yogyakarta: Buku Litera.

\section{Sumber Naskah:}

Alkhajar, E. N. S. (2020). Komunikasi Termediasi dan Momentum Revitalisasi Pembelajaran Daring. In E. N. S. Alkhajar \& S. H. B. Wijaya (Eds.), Dinamika Komunikasi dalam Pandemi COVID-19 (pp. 181-194). Yogyakarta: KBM Indonesia. 